\title{
Credit Access in the Northern Mountainous Region of Vietnam: Do Ethnic Minorities Matter?
}

\author{
Do Xuan Luan ${ }^{1,2}$ \& Nguyen Thi Lan $\mathrm{Anh}^{3}$ \\ ${ }^{1}$ Faculty of economics and rural development, Thai Nguyen University of Agriculture and Forestry, Vietnam \\ ${ }^{2}$ Institute of Project and Regional Planning, Justus-Liebig-University, Germany \\ ${ }^{3}$ Thai Nguyen University of Economics and Business Administration, Vietnam \\ Correspondence: Do Xuan Luan, Institute of Project and Regional Planning, Justus-Liebig-University, \\ Senckenbergstrasse 3, D-35390 Giessen, Germany. Tel: 49-152-1160-4795. E-mail: doxuanluan@gmail.com
}

Received: March 9, 2015

Accepted: March 24, 2015

Online Published: May 25, 2015

doi:10.5539/ijef.v7n6p166

URL: http://dx.doi.org/10.5539/ijef.v7n6p166

\begin{abstract}
By using the Bayesian Approach to address the problem of model uncertainty and a binary logit regression, this paper examines the credit accessibility of ethnic minority households compared to Kinh households in one of the poorest regions of Vietnam-the Northern Mountainous Region. Analyses show that minorities have more disadvantages compared to the Kinh majority in terms of household endowments. Ethnic minorities are still much more limited to accessing overall rural credit, commercial credit and informal credit compared to the Kinh majority population. Although ethnic minorities are more likely to access preferential credit, they receive a smaller amount of loans in comparison to the Kinh households irrespective of loan sources. This study builds on previous research that shows that the lack of access to affordable credit can make it very difficult for the ethnic minorities to expand agricultural production and their household's livelihoods. Unless constraints with credit access are addressed, ethnic minorities might not benefit from the sustainable development of the country. Therefore, an improvement in access to credit and other resources needs more concern by national poverty reduction policies targeting ethnic minorities.
\end{abstract}

Keywords: Bayesian Model Average (BMA), credit access, ethnic minorities, northern mountainous region of Vietnam, rural households

\section{Introduction}

Sustainable growth of the country cannot be achieved without investing in all people across countries, regions and national communities (World Bank, 2009). The cultural communities of Vietnam are diverse, officially comprising 54 ethnic groups. In 2011, Vietnam's population was around 87.84 million people of which ethnic minorities accounted for about 14.5 percent (GSO, 2011). The rest of 85.5 percent were Kinh majority populations. $75 \%$ of Vietnam's minorities live in two regions including the Northern Mountains and the Central Highlands and most of these minorities remain as rural residents. More than half the districts in the Northern Mountains have 10 ethnic minority groups or more represented (World Bank, 2009). Vietnam has achieved significant success in poverty reduction. Poverty headcount rate (Note 1) has reduced from nearly $60 \%$ of the population in 1993 to $11.7 \%$ in 2011 (Baulch, 2010). Despite the overall impressive achievements, ethnic minorities have experienced lower rates of poverty reduction than the general population (See Figure 1). Ethnic minorities accounted for only $14.5 \%$ of the total population, but they make up $50 \%$ of the poor.

In Vietnam, the poverty rate is substantially higher in the Northern Mountains and Central Highlands. In contrast, better-off households are concentrated in the Red River Delta and the Southwest Region (World Bank, 2012). Although the higher overall rate of poverty is present in the Northern Mountains, Swinkels and Turk (2006) revealed that geography alone does not explain why ethnic minorities are poorer than the Kinh. In fact, Kinh populations who also live in impoverished regions are not poorer than they are elsewhere. In addition, Kinh people in the same region have achieved higher rates of poverty reduction in comparison to their ethnic minority neighbors. One of the explanatory reasons could be attributed to their different access to financial resources. 


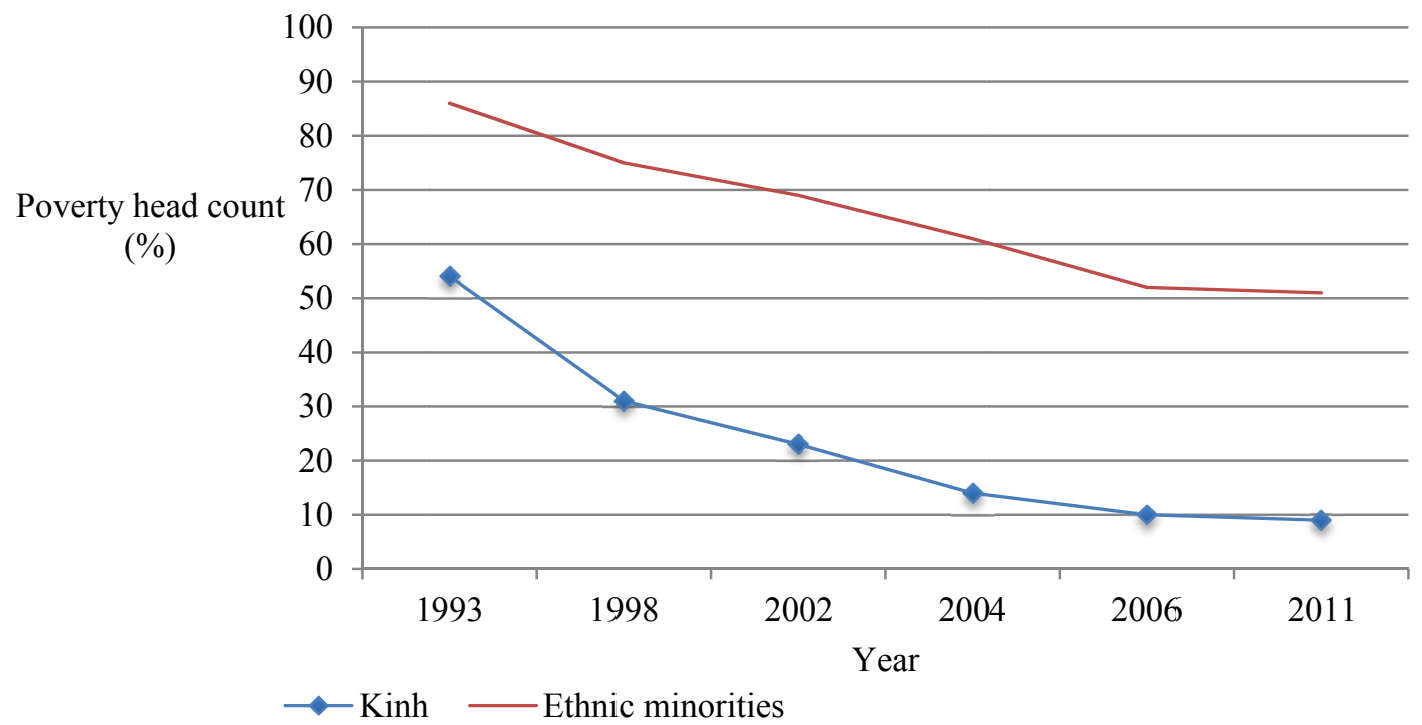

Figure 1. Poverty headcount (\%) for the Kinh majority versus ethnic minorities in Vietnam

Source: World Bank (2012).

It is believed that credit is a crucial tool to help the poor access loans, which are very important for agriculture production in disadvantaged rural areas where savings are difficult to accumulate (Guirkinger, 2008). Especially, for poor households, having sources of reliable, convenient and reasonably-priced financial tools would improve their situation (Collins et al., 2009). Hence, access to credit and other financial services has long been acknowledged as an important part of poverty reduction policies. This study aims to provide an analysis of how different household endowments explain different credit accessibility between ethnic minorities and the Kinh majority in the Northern Mountains of Vietnam. Obviously, the understanding of underlying causes is useful to improve credit access by ethnic minorities in the region.

\section{Methods and Materials}

\subsection{Data Source and Research Area}

Data used in this study is taken from the Vietnam Access Resources Household Survey (VBRHS) carried out in 2012. The total 3700 surveyed households are from 437 communes, 130 districts in 12 provinces of the country. The survey was conducted by the Institute for Policy and Strategy for rural development (ISPARD), the Central Institute for Economic Management (CIEM), the Institute for Labour Science and Social Affairs (ILSSA) under the technical support from Department of Economics at the University of Copenhagen. The financial support for the survey is from the Organization of the Danish International Development Assistance (DANIDA). Based on the objectives, this study only uses the data of 1338 households extracted from four provinces namely Lai Cai, Phu Tho, Lai Chau and Dien Bien. All those provinces are located in the Northern Mountainous Region of Vietnam.

\subsection{Methodology}

\subsubsection{Bayesian Model Average (BMA) Analysis}

George Box, a great statistician, said "All models are wrong, but some are useful". However, the selection of useful models is a particular challenge for academic researchers, especially those who specialize in the field of rural credit. This is also the most important statistical problem today in regression models (Breiman, 2001). Conventional econometric approaches such as stepwise (forward selection and backward elimination) tend to ignore the uncertainty in model selection. This might lead to unreliability in the magnitude of coefficients, standard errors and misleading interpretation of results. This paper is based on the approach of Bayesian Model Average (BMA) which is appropriate to deal with the uncertainty of model selection and make the inferences less risky than previous approaches (Hoeting et al., 1999; Raftery, 1995).

BMA is a technique of multivariate variable selection. Assume that we have a potential number of models (m) for the data $D$ which is specified by each unknown vector of parameter $\theta=\left(\theta_{1}, \theta_{2}, \ldots, \theta_{m}\right)$. A prior probability 
density $p(\theta)$ represents the uncertainty about $\theta$. The probability of observing the data $\mathrm{D}$ given true parameter $\theta$ is defined by the likelihood $\mathrm{p}(\mathrm{D} \mid \theta)$. This is also the probability that model is specified.

BMA needs prior information to impose weights for each model. Mathematically, the probability of obtaining $\theta_{\mathrm{m}}$ given model $\mathrm{m}$ is specified as $\left.\operatorname{pr}\left(\theta_{\mathrm{m}} \mid \mathrm{M}_{\mathrm{m}}\right), \mathrm{m}=1, \ldots, \mathrm{M}\right)$. In case of absenting priori information, models have same weights. Suppose that we are interested in comparing two models $M_{m}$ and $M_{l}$ with two parameters $\theta_{m}$ and $\theta_{1}$ respectively. Based on Bayes' theorem, the posterior probability that M1 is the correct model is:

$$
\operatorname{Pr}\left(M_{m} \mid D\right) \propto \operatorname{Pr}\left(M_{m}\right) * \operatorname{Pr}\left(D \mid M_{m}\right)
$$

Then the ratio of their posterior probabilities measured by the posterior odds presents the extent to which the data support $M_{m}$ over $M_{l}$. Mathematically, the ratio can be presented:

$$
\frac{\operatorname{Pr}\left(M_{m} \mid D\right)}{\operatorname{Pr}\left(M_{l} \mid D\right)}=\frac{\operatorname{Pr}\left(M_{m}\right)}{\operatorname{Pr}\left(M_{l}\right)} \cdot \frac{\operatorname{Pr}\left(D \mid M_{m}\right)}{\operatorname{Pr}\left(D \mid M_{l}\right)}
$$

The equation can be also written as:

$$
\text { Posterior odds }=\text { Bayes factor } \times \text { Prior odds }
$$

Of which: Prior odds: is often equal to 1 illustrating the absence of a prior preference for either $M_{m}$ or $M_{l}$. Bayes factor is the ratio of the integrated likelihoods for $M_{m}$ against $M_{l}$.

The Bayes factor represented by the BIC approximation (Bayesian Information Criterion) will be used as criteria for selecting appropriate models. BMA selects a set of variables such that BIC value is lowest.

For linear regression with normal errors, BIC can be written as:

$$
\mathrm{BIC}=n \log \left(R S S_{p}\right)+p \log n
$$

Where $R S S_{p}$ is residual sum squared, $\mathrm{p}$ is the number of independent variables excluding the intercept and $\mathrm{n}$ is number of observations.

The approach of Bayesian Model Average is also applied for the logistic regression or probit model. The key idea of Bayesian analysis in such models is the use of Gibbs sampling to simulate data of latent variables. Then those latent variables are introduced into the problem to obtain better parameters (Albert \& Chib, 1993). The purpose of Gibbs sampling is to compute posterior distribution of parameters and the approximate the value of latent variable. In the maximum likelihood estimation and Bayesian methods, the logit and probit models give very similar results (Tektas \& Gunay, 2008). The most important advantage of using BMA is that the choice of explanatory variables is more appropriate and estimated parameters are more accurate compared to conventional approaches. And this is particularly important for interpreting and generalizing results.

\subsubsection{A binary Logit Regression}

After selecting appropriate variables, a binary logit regression is used to analyze the credit accessibility by rural households. The dependent (binary) variable receives a value of one for all households with access to credit and a value of zero otherwise. A mixture of continuous and categorical variables reflecting the socio-economic conditions of households may explain this dependent binary variable. In the binary logit regression model, the predicted probabilities for the dependent variable will never be less than (or equal to) zero, or greater than (or equal to) one, regardless of the values of the independent variables. The linear logistic model has the form as follows:

$$
\operatorname{logit}(P) \equiv \log \left(\frac{P}{1-P}\right)=\alpha+\beta X
$$

For binary response models, the response, $\mathrm{Y}$, of a household can take on one of two possible values, denoted for convenience by 0 and 1 .

$\mathrm{X}$ is a vector of explanatory variables which captures the household characteristics. $\mathrm{X}$ includes both control variables and the variable of the most interest.

$\mathrm{P}=\operatorname{Pr}(\mathrm{Y}=1 / \mathrm{X})$ is the probability of accessing credit given $\mathrm{X}$.

$\alpha$ is the intercept parameter and $\beta$ is the vector of slope parameters.

Because Y is binary dependent variable, so the application of the Ordinary Least Square (OLS) method leads to some problems. Specifically, the errors are heteroscedastic and are a function of the parameter vector $\beta$; the predicted values can take values outside the interval of between 0 and 1 (Tektas \& Gunay, 2008). Therefore, using Maximum Likelihood Estimation (MLE) for the logit model is more appropriate in this case (Bun, 2002).

In this study, analyses are conducted for four models including the overall rural credit, preferential credit of 
VBSP, commercial credit of VBARD and the informal credit model. In the first one, all overall credit-users and credit non-users are put into analysis. In the other models, only households with access to a particular source of credit are added into analysis. The separations of those models separations allow us to examine determinants of accessing to different credit sources.

\subsubsection{The Choice of Explanatory Variables}

The selection of explanatory variables is based on the theories, data availability and potential significance for policy interventions. Those variables are important to explain credit accessibility by households and to evaluate the creditworthiness of households by lenders.

Theoretically, there could be many variables influencing credit accessibility of rural households. Suppose that credit access is a function of possible explanatory variables.

Credit access $=\mathrm{f}($ ethnic minorities, risk, social capital, age, education, family size, nonfarm income, extension, membership of local associations, distance to market, asset, land fragmentation).

In order to reliably infer the causal relationship between the ethnicity and credit access, other independent variables (control variables) are also included in the credit access model. The description and hypotheses of how each variable influences credit access are reported in Table 1.

Table 1. Description and assumptions of selected explanatory variables

\begin{tabular}{|c|c|c|c|}
\hline Variables & Type & Description & Expected sign \\
\hline Help & Continuous & The number of people known who could be asked for help (persons) & + \\
\hline Relation & Binary & $\begin{array}{l}\text { Households have members, relatives or friends holding office or other trusted } \\
\text { position in the communes }(1=\text { Yes })\end{array}$ & + \\
\hline Risk & Binary & Household suffered risks over the previous 12 months $(1=$ Yes $)$ & - \\
\hline Risk losses & Continuous & Economic losses caused by agricultural and health risks (VND 1000) & - \\
\hline Age & Continuous & General education of household heads (years in school) & $+/-$ \\
\hline Family size & Continuous & Total members of the household (persons) & $+/-$ \\
\hline Nonfarm & Continuous & Share of non-farm income in total household income $(\%)$ & \\
\hline Extension & Binary & Households have access to extension services ( $1=$ Yes) & + \\
\hline Visits & Continuous & $\begin{array}{l}\text { Number of household visits to agricultural extension in the last } 12 \text { months and vice } \\
\text { versa (number) }\end{array}$ & + \\
\hline Savings & Continuous & Total value of savings (VND 1000) & - \\
\hline Union & Binary & Membership of women's unions $(1=$ Yes $)$ & + \\
\hline Asset & Continuous & Total value of household asset (VND 1000) & + \\
\hline Plot & Continuous & The number of land plots household own (number) & $+/-$ \\
\hline
\end{tabular}

Source: Based on prior expectations.

A brief description and assumptions of control variables and variables of interest are presented as follow:

\subsubsection{The Variables of the Most Interest}

Ethnicity is the variable of the most interest. This binary variable captures the difference between the ethnic minorities and the Kinh ethnic majority. It receives a value of one for ethnic minority households and is zero otherwise. Ethnic minorities include Tay, Nung, Dao, H’Mong and some other ethnic minority groups.

\subsubsection{Control Variables}

Social: In this study, two variables are used as proxies for social capital of households. The first continuous one (Help) indicates the number of people known who could be asked for help. Burt (2000) indicated that social capital refers to friends, colleagues, and more general contacts through which households receive opportunities to use other forms of capital. The theory of social capital can be applicable to the rural credit market. Dufhues et al. (2011) also argued that social capital of households also explains their credit repayment performance and therefore relates to creditworthiness of households. The second one, Relation, which is a binary variable 
receiving a value of 1 for cases in which households have members, relatives or friends holding office or other trusted positions in the communes. It is expected that households with better relationships to local authorities might have better access to credit (Behr et al., 2011).

Risk: This binary variable receives a value of one for households, which suffer from unexpected risks, and otherwise zero.

Risk losses: It is assumed that economic losses caused by agricultural and health risks can push rural households into further poverty or indebtedness. Farm households, especially the poor ones are the most vulnerable in Vietnam (GSO, 2012b). Therefore, access to financial services such as credit and insurance is very important for farmers because of two such services might help farmers to cope with risks and improve their agricultural production efficiency (Skees \& Barnett, 2006).

Age: Age of the household head might represent the social reputation and attitude to debt. Moreover, age is likely to correlate with income or consumption over time. Income generated by household heads and their family increases to a peak as their career develops then declines when they get older (Zeller \& Sharma, 2002).

Education (years in school): A household head with a higher level of education is believed to be a better manager regarding farm household decisions, performing better risk management and higher income generation. This variable also reveals the social reputation in rural society because societies highly appreciate people who have a higher educational level. Moreover, education level also represents the potential to work in off-farm activities. From the point of view of lenders, they are likely to believe that more educated households are more creditworthy than less educated ones (Khalid, 2003; Okurut, 2006).

Family size: This variable can represent the labor potential of the farm household as well as the dependency ratio. On the one hand, a larger household size might indicate a greater number of laborers, which is a potential for the household's future income and repayment ability. On the other hand, a larger household size might increase the dependency ratio (measured by taking the number of people outside the working age range divided by the number of people aged within the range (16-60 years). Consequently, households with a higher number of dependents are considered to be less able to improve their living standard and hence, less creditworthy (Bao, Duong, \& Izumida, 2002).

Nonfarm: The share of non-farm activities in total yearly income refers to that portion of farm household income obtained off the farm, including nonfarm wages and salaries, pensions, and interest income earned by farm families. Stampini and Davis (2009) concluded that households engaging in off-farm labor activities spend significantly more on seeds, services, hired labor and livestock inputs. Encouraging access to off-farm activities may serve as a substitute for access to credit.

Extension: This variable reflects the access and the numbers of household visits to the agricultural extension stations in the last 12 months and vice versa. Agricultural extension services are assumed to help farmers manage and use resources more effectively. At the same time, maintaining relationships with agricultural extension stations might improve the household's social capital to improve access to other services such as credit (Mahajan \& Vasumathi, 2010).

Savings: This variable reflects the total value of savings, which might represent collateral security and household ownership as physical capital. In addition, it is a good indicator of the repayment capability of a household. Savings are essential for the extremely poor who strongly rely on their own savings and depend on informal credit to prevent food shortages and starvation (Wright et al., 1997).

Union: Membership of women's unions might improve household social networks. Women's participation in credit programs is helpful into improving women's empowerment, women's mobility and their social interactions at the community level (Pitt et al., 2006). Hence, these households may better access credit programs.

Distance: The distance of the household to the commune center is used to capture the transaction costs to obtain credits as well as the market access conditions of households. It is expected that a greater distance increases transaction costs in accessing credit and the market. In return, higher transaction costs are expected to have a negative impact on loan repayment. (Khoi et al., 2013) and Stanton (2002) argued that infrastructure has a link to transaction costs of obtaining loans. In this aspect, better infrastructure could enhance profitable business activities that cover loan costs.

Asset: This variable reveals the total value of household assets, which might represent the relative wealth level of households. Access to credit is determined by relative wealth status of households rather than collateral ownership (Takahashi et al., 2010). 
Plot: This variable indicates the number of land plots households own. It is assumed that land fragmentation might discourage the use of other necessary inputs such as fertilizer, pesticides, agricultural extension, irrigation services, and so on. Zeller and Sharma (2002) showed that household demand for credit depends on availability of agricultural production inputs rather than farm size.

\section{Results}

\subsection{Credit Sources Categorized by Ethnicity Groups}

In the Northern Mountainous Region of Vietnam, rural households borrow from two main credit sources namely from the formal and informal sectors. The formal sector is composed of the two state-owned banks including Vietnam Bank for Social Policy (VBSP), Vietnam Bank for Agriculture and Rural Development (VBARD) and People's Credit Funds (PCFs). The informal credit sector comprises all lenders such as private lenders (shopkeepers, moneylenders, or any lender without a family relationship or friendship with the borrower) and household friends and relatives. Table 2 presents the distribution of selected households in terms of credit access and ethnic groups.

Table 2. Distribution of households in terms of credit sources and ethnicity

\begin{tabular}{|c|c|c|c|c|c|c|}
\hline \multirow{2}{*}{ Credit sources } & \multicolumn{2}{|c|}{ Kinh } & \multicolumn{2}{|c|}{ Ethnic minorities } & \multicolumn{2}{|c|}{ All sample } \\
\hline & Frequency & $\%$ & Frequency & $\%$ & Frequency & $\%$ \\
\hline Non-accessed & 260 & 65.16 & 638 & 67.94 & 898 & 67.12 \\
\hline Accessed & 139 & 34.84 & 301 & 32.06 & 440 & 32.88 \\
\hline Only Vietnam Bank for Social Policy (VBSP) & 37 & 9.27 & 207 & 22.04 & 244 & 18.24 \\
\hline $\begin{array}{l}\text { Only Vietnam Bank for Agriculture and Rural } \\
\text { Development (VBARD) }\end{array}$ & 40 & 10.03 & 27 & 2.88 & 67 & 5.01 \\
\hline Only People's Credit Funds (PCF) & 3 & 0.75 & 2 & 0.21 & 5 & 0.37 \\
\hline Only UNION & 9 & 2.26 & 7 & 0.75 & 16 & 1.20 \\
\hline Only informal & 42 & 10.53 & 50 & 5.32 & 92 & 6.88 \\
\hline VBSP \& informal & 7 & 1.75 & 5 & 0.53 & 12 & 0.90 \\
\hline VBARD \& VBSP & 0 & 0.00 & 3 & 0.32 & 3 & 0.22 \\
\hline VBARD \& PCF & 1 & 0.25 & 0 & 0.00 & 1 & 0.07 \\
\hline Total & 399 & 100 & 939 & 100 & 1338 & 100 \\
\hline
\end{tabular}

Note. UNION represents Farmer's/Veteran's/Women's Union.

Source: own calculation.

The Vietnam Bank for Agriculture and Rural Development (VBARD), the biggest state owned commercial bank, was established in 1990. It has provided commercial credit for agricultural and rural areas, which account for more than $50 \%$ of its total outstanding loan volume (GSO, 2012a). The major form of government intervention in rural credit markets in Vietnam is the extension preferential loans of Vietnam Bank for Social Policy (VBSP) to low-income agricultural households. Preferential credit can be received via the bank. Borrowers pay only part of the commercial interest rate, whereas the remainder is paid by the government. There is hence, a subsidy of the interest rate. Since 2003, preferential credit has been handed out by the Vietnam Bank for Social Policy. The bank has provided 11 programs of lending to low income households. These credit programs comprise loans for the poor households, extremely disadvantaged ethnic minority households, programs for business and production households living in extremely disadvantaged areas and communes, etc. In the country, after the collapse of rural credit cooperatives in the late 1980s, a network of People's Credit Funds (PCFs) was established. The key objective of PCFs is to build the confidence of rural people in the formal credit system, to reform and strengthen the country's rural banking system. PCFs are commune-based entities, jointly owned, operated and managed by their members to provide savings and credit services. PCFs are operating based on the economic principle of cost covering. However, PCFs have been established in regions with better socio-economic development. The targeted customers of PCFs are farms, small and medium enterprises rather than poor farm households. Therefore, the network plays a limited role in proving credit to the rural poor and poverty reduction (Putzeys, 2002).

Although rural credit has been increased in recent years, there is still a large proportion (nearly $70 \%$ ) of households without credit access. A majority of rural households have access to formal credit sources, while a 
minority of them has access to informal credit. This situation reflects the dominant role of formal credit in providing credit to rural households in the region. Moreover, households with access to preferential credit by VBSP occupy the largest proportion, followed by informal credit and VBARD. Households with access to credit of the People's Credit Fund merely represent more than 1\% of total households. So, the formal credit market is mainly provided by the two lenders consisting of VBSP and VBARD.

Regarding the ethnicity aspect, the Kinh appear to obtain credit from the Bank for Agriculture and Rural Development (VBARD) and informal credit while minorities tend to take mostly subsidized loans from the Vietnam Bank for Social Policy (See Figure 2). Several policies, which intend to reduce poverty among ethnic minorities have been implemented in recent years namely the Government Decree No.78/2002/ND-CP and Decision 32/2007/QD-TTg. Due to the expansion of preferential lending policies, minorities appear to have better access to this source.

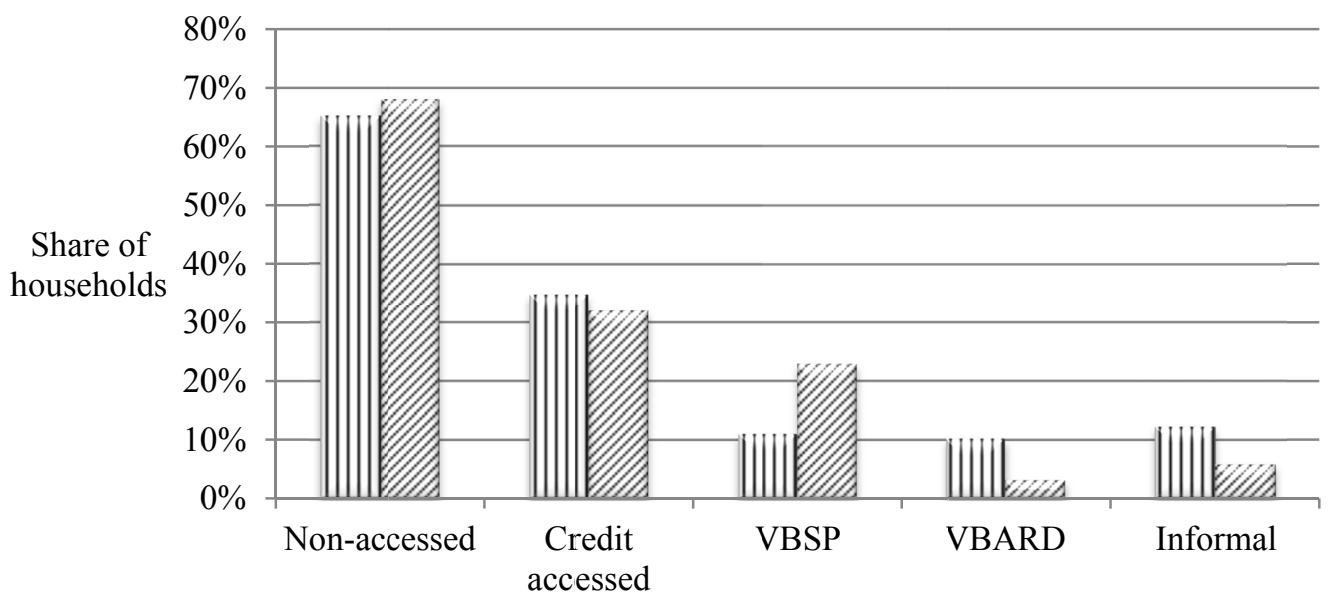

Credit sources

uKinh $\triangle$ Ethnic minorities

Figure 2. Sources of loans by ethnic groups

Source: own graph.

\subsection{Endowment Differences between Two Ethnicity Groups}

\subsubsection{Difference in Household Income}

Figure 3 illustrated by the box plot presents the means and standard deviations of total household income between ethnic minorities and Kinh majority. The average income of the Kinh is much higher when compared to ethnic minorities and the difference is statistically significant at $1 \%$ level (Note 2). The explanatory factors for this situation might include variations in the quality and quantity of household resources allocated for economic activities. It might also be due to unequal access to financial assets such as credit. 


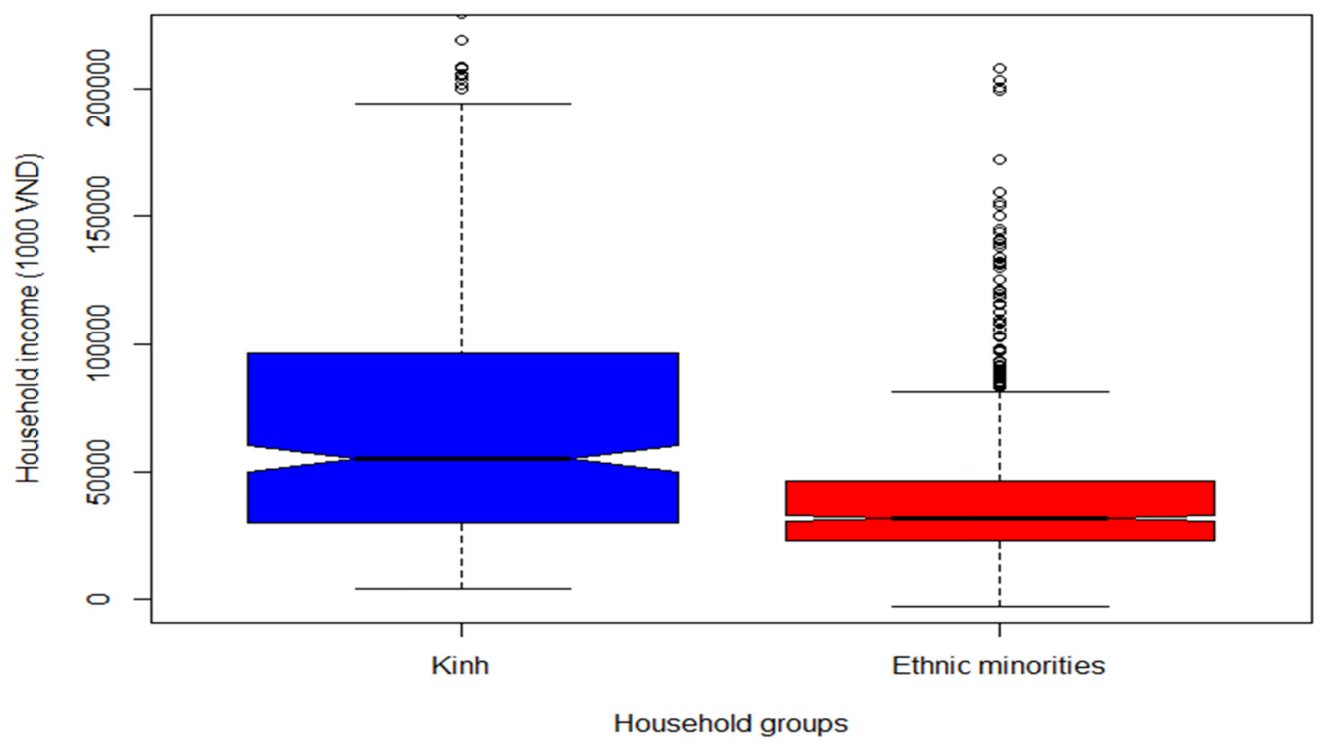

Figure 3. Income difference between Kinh and ethnic minorities

Source: own graph.

\subsubsection{Difference in Other Household Endowments}

The differences in household endowments between the two household groups can explain the disadvantages of ethnic minorities compared to the Kinh people. Table 3 presents the t-statistics and Pearson Chi squared tests (Note 3 ) for the differences in means of selected variables between two ethnic groups subcategorized by credit access. Accordingly, minorities have more disadvantages compared to the Kinh majority on most of indicators. Specifically, the Kinh people tend to have a higher value of assets and savings compared to minorities. Land, which tends to be much more fragmented in the case of minorities, might discourage ethnic minorities from agricultural investment and productivity improvement. One constraint in socio-economic transactions of ethnic minorities is that they live further away from the market center. Higher transaction costs could be a disadvantage to access information, adopt new ideas and expand social networks. Extension is important for minorities in rice terrace cultivation which is different from the cultivation of the rice fields in the lowlands. The table further shows that there is no difference in share of households with access to extension services, but the number of visits to extension services is significantly higher in the case of the Kinh majority. In addition, minorities tend to have a larger family size, creating the likelihood of having more family dependents. The share of risk affected households and the amount of risk losses are significantly higher in the case of ethnic minorities who are much more vulnerable to risks. Cultural constraints could be a reason for lower participation of ethnic minority females in local women's unions. This might limit women's benefits from accessing social networks in minority communities.

Table 3. Differences in means of selected variables

\begin{tabular}{lcccccc}
\hline & \multicolumn{2}{c}{ No credit } & \multicolumn{2}{c}{ Credit access } & \multicolumn{2}{c}{ All sample } \\
Variables & Kinh & Ethnic & Kinh & Ethnic & Kinh & Ethnic \\
majority & minorities & majority & minorities & majority & minorities \\
\hline Help & $3.85^{* * *}$ & 2.97 & 4.19 & 3.67 & $3.97^{* * *}$ & 3.19 \\
Relation & .28 & .26 & $.41^{* *}$ & .29 & $.32^{* *}$ & .27 \\
Risk & $.47^{* * *}$ & .77 & $.68^{* * *}$ & .82 & $.54^{* * *}$ & .78 \\
Loss & $2317^{* * *}$ & 4777 & 4185 & 5021 & $2968^{* * *}$ & 4855 \\
Age & $54.02^{* * *}$ & 46.50 & $49.78^{* * *}$ & 43.83 & $52.54^{* * *}$ & 45.64 \\
Education & $8.49^{* * *}$ & 9.25 & 9.16 & 8.68 & $8.72^{*}$ & 9.07 \\
Family size & $3.45^{* * *}$ & 5.50 & $3.87^{* * *}$ & 5.51 & $3.60^{* * *}$ & 5.50 \\
\hline
\end{tabular}




\begin{tabular}{lcccccc}
\hline Nonfarm & $.13^{* * *}$ & .03 & $.17^{* * *}$ & .05 & $.14^{* * *}$ & .03 \\
Extension & .49 & .50 & .57 & .53 & .52 & $1.74^{* * *}$ \\
Visits & $1.80^{* * *}$ & 1.10 & 1.63 & 1.51 & 733 \\
Savings & $27789^{* * *}$ & 5111 & $7894^{*}$ & 4135 & $20858^{* * *}$ & 4798 \\
Union & $.11^{* * *}$ & .03 & $.11^{* * *}$ & .03 & $.11^{* * *}$ & .03 \\
Asset & $19574^{* * *}$ & 11522 & $26719^{* * *}$ & 11631 & $22063^{* * *}$ & 11557 \\
Plot & $8.39^{* * *}$ & 11.64 & $9.32^{* * *}$ & 11.85 & $8.71^{* * *}$ & 11.71 \\
Distance & $1.47^{* * *}$ & 4.96 & $1.69^{* * *}$ & 4.25 & $1.55^{* * *}$ & 4.73 \\
\hline
\end{tabular}

Note. Absolute value of standard deviation in parentheses; ** significant at $5 \%$; $* * *$ significant at $1 \%$.

Source: own calculation.

\subsection{Ethnic Minorities and Credit Accessibility}

Table 4 presents the explanatory variables selected by the approach of Bayesian Model Average (BMA), and the Probit regression. LR chi-square statistics are equal to 73.33, 59.29, 56.02 and 27.46 for pooled, VBSP, VBARD and informal credit model respectively. These results lead to reject the null hypotheses that all parameters in three models are equal to zero. In other words, all models are appropriate at the confidence level of $99 \%$. The Probit models predicted $68.16,80.64,94.62$ and $92.45 \%$ of all households correctly. These results indicate that the goodness of fit is satisfied.

As expected, control variables also influence credit access by rural households. Those variables are important because they not only explain the determinants of credit access but serves for adjusting the coefficient of Ethnicity variable- the variable of the most interest. The social capital related variable reflected by the number of helpers is positively associated with credit accessibility by households. This result agrees with the finding of Story and Carpiano (2015), which indicated that a better connection with helpers facilitates household social capital and credit access.

The coefficient of Nonfarm is positive and significant for the overall credit and formal commercial credit model. Households with a higher proportion of off-farm income might need better skills to run other business activities. In addition, these households might have laborers, who work for governmental organizations or companies, which require higher levels of qualification. Non-farm income is also useful for households to smooth consumption in the case of crop losses or other unexpected risks. As expected, households with a higher share of non-farm income have better access to credit, especially non-preferential credit sources. This finding favors the statement of Simtowe et al. (2006), which showed that households with a higher share of nonfarm income are more likely to access technologies, be less vulnerable to risks and achieve creditworthiness.

Table 4. Logistic estimation of credit accessibility

\begin{tabular}{lcccc}
\hline Explanatory variables & Overall credit & VBSP & VBARD & Informal \\
\hline Intercept & -.36 & $-1.61^{* * *}$ & $-2.73^{* * *}$ & $-2.63^{* * *}$ \\
Control variables & & & & $.04^{* *}$ \\
$\quad$ Help & $.04^{* * *}$ & $.05^{* * *}$ & & $.76^{* * *}$ \\
Risk & $.60^{* * *}$ & $.53^{* * *}$ & & \\
Age & $-.02^{* * *}$ & $-.02^{* * *}$ & & \\
$\quad$ Nonfarm & $.83^{* *}$ & & $1.93^{* * *}$ & \\
Extension & $.09^{* * *}$ & & $.17^{* * *}$ & \\
$\quad$ Savings & $-.0000161^{* * *}$ & $-.000012^{* *}$ & $-.0000103^{*}$ & \\
Variable of interest & & & & \\
$\quad$ Ethnicity & $-.37^{* *}$ & $.58^{* * *}$ & $-1.00^{* * *}$ & $-.97^{* * *}$ \\
Number of observations & 1338 & 1338 & 1338 & 1338 \\
LR chi2(7) & 73.33 & 59.29 & 56.02 & 27.46 \\
Prob > chi2 & 0.0000 & 0.0000 & 0.0000 & 0.0000 \\
Correctly classified (\%) & 68.16 & 80.64 & 94.62 & 92.45 \\
\hline
\end{tabular}

Note. ${ }^{* *}$ Significant at $5 \% ; * * *$ significant at $1 \%$.

Source: own calculation. 
Households with access to agricultural extension services are likely to access credit. This conclusion is confirmed by the overall and formal commercial credit models. Agricultural extension services are expected to not only improve knowledge, agricultural production skills but also provide households with necessary information about credit sources and credit institutions. In addition, those households are more likely to also be members of local mass organizations such as farmer's unions, which often play an intermediate role in loan disbursement. This argument agrees with the findings of Buadi et al. (2013) and Okten and Osili (2004), which report that access to extension services is significant to help famers manage and use resources more effectively as well as provide information about credit programs to potential borrowers.

The coefficient of Savings is negative and significant at the $5 \%$ level for all credit models except informal credit. Results indicate that households with higher amounts of savings are less likely to take loans. The reason could be attributed by the fact that savings are substitutable for loans to meet household demands of investment. This result is in line with the finding of Dong et al. (2012), which reported that savings can also serve as a self-insurance tool and a financial substitution source for credit.

Risk has a positive coefficient indicating that risk affected households are more likely to access credit. This coefficient is particularly significant for all credit models except the VBARD model. The poor are not only more affected by personal risks but also by weather conditions and fluctuation of market prices. Risks might reduce land productivity, crop yield and household income. Perhaps, one possible way of poorer households to respond to risks is to take loans.

In term of Age of household heads, lenders tend to provide loans to younger clients who might represent a potential for improving agricultural production within this economic age range and can be members of the credit institutions for a longer time.

The variable of the most interest is Ethnicity, which has statistically significant coefficients in all credit models. Ethnic minority households are more likely to access preferential credit by VBSP but less likely to access overall rural credit, especially commercial credit from VBARD and informal sources. These results are quite consistent with the mission of VBSP to provide credit to the poor, especially ethnic minorities. In realities, a majority of borrowers of preferential credit are ethnic minorities, who are poorer than the Kinh majority in the same region. The fact that the poorer households benefit less from accessing credit is also found in Thailand, a neighboring country with Vietnam. Coleman (2006) evaluated the impact of two microfinance programs in Northeast Thailand. His paper highlighted the positive impact of accessing credit but only for non-poor borrowers.

\subsection{Ethnic Minorities and Credit Amounts}

Improving access to loans by ethnic minorities also means increasing their amounts of credit as much as possible. Loan providers normally restrict the maximum amount of loans they are willing to grant because they are concerned very much about the ability of borrowers to repay. Figure 4 illustrated by an error bar graph presents the means and standard deviations of credit amount in each accessed households categorized by ethnicity. The graph also provides the visualization of mean comparison in loan amounts between groups.
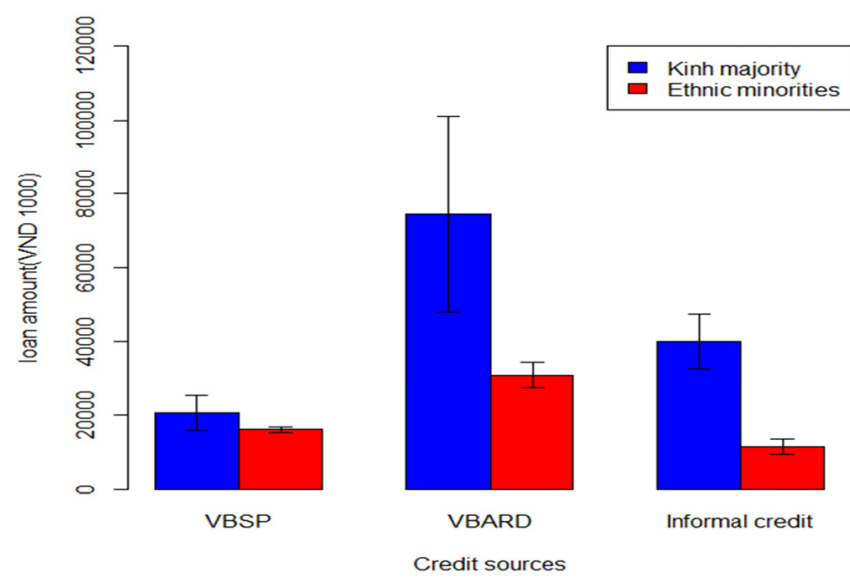

Figure 4. Distribution of loan amounts categorized by ethnicity groups

Source: own graph. 
It is observed that distribution of loan amount is quite different among groups. Minorities significantly obtain smaller loans compared to the Kinh for all credit sources (Note 4). This could be explained by the fact that preferential loans for minorities come mostly from VBSP, which has a credit limit policy (around 30 million VND or less). Smaller amounts of loans might target poorer households. The deeper outreach of preferential credit is remarkably due to the policy of subsidized interest rates. In contrast, credit of VBARD is mainly offered to the wealthier households who qualify for higher amounts. Loans from VBARD often have higher interest rates and need collateral requirements such as land use certificates. In addition, loan amounts tend to vary significantly in case of the Kinh accessed households. This could be explained by the fact that the loan amount of the Kinh households may be adjusted in the case of VBARD because borrowers and lenders are more flexible to negotiate their credit contracts. Smaller loans from preferential credit might be insufficient for ethnic minority households to expand production and improve livelihood. This argument is supported by the findings of Coleman (1999) and Bauchet and Morduch (2013), which have a common implication that small loans have no significant impacts on farm profits. van Rooyen et al. (2012) also showed that small loans have higher probability of harming the poorest households in Sub-Saharan Africa and credit intervention by itself seems to have no significant impact.

\section{Conclusion and Discussion}

This paper has attempted to provide an understanding of the difference in household endowments and credit access between ethnic minorities and the Kinh majority in the Northern Mountains of Vietnam. Although the government has paid great attention to the development of minorities, a number of disadvantages including limited access to extension and credit still remain. Specifically, this study shows that ethnic minorities are less likely to access overall rural credit, credit of VBARD and informal credit. Although minorities have better access to preferential credit, they still receive smaller amounts of loans compared to the Kinh majority regardless of credit sources. The shortage of credit might make it very difficult for ethnic minorities to expand their production and diversify their likelihoods. Subsidized loans from the Bank for Social Policy are important, but the credit amounts from this source are limited. If the ethnic minorities are still limited in their access to credit while the lack of capital is one of the main reasons in explaining their poverty situations, then the economic growth might not benefit all people throughout the country.

Therefore, to improve the credit access by ethnic minorities, a policy with comprehensive socio-economic dimensions should be also considered. The average size of formal loans could be raised for ethnic minorities. However, the provision of credit to ethnic minorities needs to consider the purposes of credit use, the seasonality of farming activities as well as their cash flow of income and expenditure. The development of risk-coping capacities such as agricultural insurance and health care insurance could not only help ease the credit access constraints but also enhance the welfare impact of credit. Ethnic minorities in the research areas face various types of risks, especially from natural conditions. However, farm households have little risk prevention measures as none of them are covered by any type of agricultural insurance. In addition, ethnic minorities also need non-financial services such as business skills, market access, agricultural extension services and infrastructure improvement.

\section{Acknowledgements}

We would like to thank the Vietnamese Central Institute for Economic Management (CIEM), Vietnamese Institute of Policy and Strategies for Agriculture and Rural Development (IPSARD) for providing the data. We also thank Ms. Battista for English correction of the text.

\section{References}

Albert, J. H., \& Chib, S. (1993). Bayesian-Analysis of Binary and Polychotomous Response Data. Journal of the American Statistical Association, 88(422), 669-679. http://dx.doi.org/10.1080/01621459.1993.10476321

Bao Duong, P., \& Izumida, Y. (2002). Rural Development Finance in Vietnam: A Microeconometric Analysis of Household Surveys. World $\quad$ Development, $30(2), \quad 319-335$. http://dx.doi.org/10.1016/S0305-750X(01)00112-7

Bauchet, J., \& Morduch, J. (2013). Is Micro too Small? Microcredit vs. SME Finance. World Development, 43, 288-297. http://dx.doi.org/10.1016/j.worlddev.2012.10.008

Baulch, B. (2010). Ethnic minority poverty in Vietnam. Chronic Poverty Research Centre Working Paper, (169). http://dx.doi.org/10.2139/ssrn.1719672

Behr, P., Entzian, A., \& Güttler, A. (2011). How do lending relationships affect access to credit and loan conditions in microlending? Journal of Banking \& Finance, 35(8), 2169-2178. 
http://dx.doi.org/10.1016/j.jbankfin.2011.01.005

Breiman, L. (2001). Statistical Modeling: The Two Cultures (with comments and a rejoinder by the author).

Buadi, D. K., Anaman, K. A., \& Kwarteng, J. A. (2013). Farmers' perceptions of the quality of extension services provided by non-governmental organisations in two municipalities in the Central Region of Ghana. Agricultural Systems, 120(0), 20-26. http://dx.doi.org/10.1016/j.agsy.2013.05.002

Bun, M. J. G. (2002). A guide to modern econometrics. Economist-Netherlands, 150(3), 320-321.

Burt, R. S. (2000). The Network Structure Of Social Capital. Research in Organizational Behavior, 22, 345-423. http://dx.doi.org/10.1016/S0191-3085(00)22009-1

Coleman, B. E. (1999). The impact of group lending in Northeast Thailand. Journal of Development Economics, 60(1), 105-141. http://dx.doi.org/10.1016/S0304-3878(99)00038-3

Coleman, B. E. (2006). Microfinance in Northeast Thailand: Who benefits and how much? World Development, 34(9), 1612-1638. http://dx.doi.org/10.1016/j.worlddev.2006.01.006

Collins, D., Morduch, J., Rutherford, S., \& Ruthven, O. (2009). Portfolios of the poor: How the world's poor live on $\$ 2$ a day. Princeton University Press.

Dong, F., Lu, J., \& Featherstone, A. (2012). Effects of Credit Constraints on Household Productivity in Rural China. Agricultural Finance Review, 72(3), 402-415. http://dx.doi.org/10.1108/00021461211277259

Dufhues, T., Buchenrieder, G., Quoc, H. D., \& Munkung, N. (2011). Social capital and loan repayment performance in Southeast Asia. The Journal of Socio-Economics, 40(5), 679-691. http://dx.doi.org/10.1016/j.socec.2011.05.007

GSO, General Statistics Office of Vietnam. (2011). Statistical Handbook of Vietnam. Ha Noi: Statistical Publishing House.

GSO, General Statistics Office of Vietnam. (2012a). Statistical Handbook of Vietnam. Ha Noi: Statistical Publishing House.

GSO, General Statistics Office of Vietnam. (2012b). The Vietnam Household Living Standards Survey. Hanoi: Statistical Publishing House.

Guirkinger, C. (2008). Understanding the Coexistence of Formal and Informal Credit Markets in Piura, Peru. World Development, 36(8), 1436-1452. http://dx.doi.org/10.1016/j.worlddev.2007.07.002

Hoeting, J. A., Madigan, D., Raftery, A. E., \& Volinsky, C. T. (1999). Bayesian Model Averaging: A Tutorial. Statistical Science, 14(4), 382-417.

Khalid, M. (2003). Access to formal and quasi-formal credit by smallholder farmers and artisanal fishermen: A case of Zanzibar. Mkuki na Nyota Publishers.

Khoi, P. D., Gan, C., Nartea, G. V., \& Cohen, D. A. (2013). Formal and informal rural credit in the Mekong River Delta of Vietnam: Interaction and accessibility. Journal of Asian Economics, 26, 1-13. http://dx.doi.org/10.1016/j.asieco.2013.02.003

Mahajan, V., \& Vasumathi, K. (2010). Combining Extension Services with Agricultural Credit: The Experience of BASIX India. Innovations in Rural and Agriculture Finance.

Okten, C., \& Osili, U. O. (2004). Social Networks and Credit Access in Indonesia. World Development, 32(7), 1225-1246. http://dx.doi.org/10.1016/j.worlddev.2004.01.012

Okurut, F. N. (2006). Access to credit by the poor in South Africa: Evidence from Household Survey Data 1995 and 2000. Department of Economics, University of Botswana Stellenbosch Economic Working Papers, $13(06)$

Pitt, M. M., Khandker, S. R., \& Cartwright, J. (2006). Empowering women with micro finance: Evidence from Bangladesh. Economic Development and Cultural Change, 54(4), 791-831. http://dx.doi.org/10.1086/503580

Putzeys, R. (2002). Micro finance in Vietnam: Three case studies. Rural Project Development, Hanoi.

Raftery, A. E. (1995). Bayesian Model Selection in Social Research. Sociological Methodology, 25, 111-163. http://dx.doi.org/10.2307/271063

Simtowe, F., Zeller, M., \& Phiri, A. (2006). Determinants of Moral Hazard in Microfinance: Empirical Evidence from Joint Liability Lending Programs in Malawi. African Review of Money Finance and Banking, 5-38. 
Skees, J. R., \& Barnett, B. J. (2006). Enhancing microfinance using index-based risk-transfer products. Agricultural Finance Review, 66(2), 235-250. http://dx.doi.org/10.1108/00214660680001189

Stampini, M., \& Davis, B. (2009). Does nonagricultural labor relax farmers' credit constraints? Evidence from longitudinal data for Vietnam. Agricultural economics, 40(2), 177-188. http://dx.doi.org/10.1111/j.1574-0862.2009.00368.x

Stanton, J. (2002). Wealth and Rural Credit among Farmers in Mexico: Is Market Paprticipation Consistent with Targeting? In M. Zeller \& R. L. Meyer (Eds.), Triangle of Microfinance: Financial Sustainability, Outreach and Impact. London: The John Hopkins University Press Baltimore

Story, W. T., \& Carpiano, R. (2015). Household social capital and socioeconomic inequalities in child undernutrition in rural India: Exploring institutional and organizational ties. Annals of Global Health, 81(1), 119-120. http://dx.doi.org/10.1016/j.aogh.2015.02.775

Swinkels, R., \& Turk, C. (2006). Explaining ethnic minority poverty in Vietnam: A summary of recent trends and current challenges. Paper presented at the Background paper for CEM/MPI meeting on Ethnic Minority Report.

Takahashi, K., Higashikata, T., \& Tsukada., K. (2010). The short-term poverty impact of small-scale, collateral free microcredit in Indonesia: A matching estimator approach. The Developing Economics, 48, 128-125. http://dx.doi.org/10.1111/j.1746-1049.2010.00101.x

Tektas, D., \& Gunay, S. (2008). A Bayesian Approach to Parameter Estimation in Binary Logit and Probit models. Hacettepe Journal of Mathematics and Statistics, 37(2), 167-176.

Van Rooyen, C., Stewart, R., \& De Wet, T. (2012). The Impact of Microfinance in Sub-Saharan Africa: A Systematic Review of the Evidence. World Development, 40(11), 2249-2262. http://dx.doi.org/10.1016/j.worlddev.2012.03.012

World Bank, WB. (2012). Well Begun, Not Yet Done: Vietnam's Remarkable Progress on Poverty Reduction and the Emerging Challenges.

World Bank. (2009). Country Social Analysis (Vol. 9976, p. 78). Ethnicity and Development in Vietnam: Summary Report.

Wright, G., Hossain, M., \& Rutherford, S. (1997). Savings: Flexible Financial Services for the Poor. In G. Wood \& I. Sharif (Eds.), Who Needs Credit? Poverty and Finance in Bangladesh. Bangladesh: Dhaka University Press.

Zeller, M., \& Sharma, M. (2002). Access to and Demand for Financial Services by the Rural Poor: A Multicountry Synthesis. In M. Zeller \& R. L. Meyer (Eds.), The Triangle of Microfinance: Financial Sustainability, Outreach and Impact. London: The John Hopkins University Press Baltimore.

\section{Notes}

Note 1. The national poverty line based on Decision 09/2011/QD-TTg of Vietnamese Government for the period 2011-2015 is VND 400, 000 monthly capita income.

Note 2. T-statistic is computed to test the difference in average income: $\mathrm{t}$-test $=9.26$ and $\mathrm{p}$-value $=0.0000$;

Note 3. T-statistics are computed for continuous variables and Peason chi2 is applied for discrete variables to test the difference in means of selected variables between ethnic minorities and Kinh majority.

Note 4. T-statistics are employed to test the differences in means of loan amounts received by ethnic minority households and Kinh majority households: t-test=3.11, 1.99, 2.29 and 3.68 for the overall credit, preferential credit of VBSP, commercial credit of VBARD and informal sources respectively.

\section{Copyrights}

Copyright for this article is retained by the author(s), with first publication rights granted to the journal.

This is an open-access article distributed under the terms and conditions of the Creative Commons Attribution license (http://creativecommons.org/licenses/by/3.0/). 